\title{
Fermentative profile and nutritional value of elephant grass silage with different levels of crude glycerin
}

\section{Perfil fermentativo e valor nutricional da silagem de capim-elefante com diferentes níveis de glicerina bruta}

\author{
João Paulo Sampaio Rigueira ${ }^{1}$; Flávio Pinto Monção ${ }^{2 *}$; Eleuza Clarete Junqueira de \\ Sales $^{1}$; Sidnei Tavares dos Reis ${ }^{3}$; Lara Maria Santos Brant ${ }^{4}$; Julieta Maria Alencar \\ Chamone ${ }^{1}$; Vicente Ribeiro Rocha Júnior ${ }^{1}$; Daniel Ananias de Assis Pires ${ }^{1}$
}

\begin{abstract}
This study aimed to evaluate the best level of inclusion of crude glycerin in elephant grass (Pennisetum purpureum Schum.) silage on fermentative profile, chemical composition and ruminal degradation of dry matter and fiber fraction in elephant grass silages. The experiment was conducted in a completely randomized design being used elephant grass cv. Napier with four levels of inclusion of glycerin (1, $5,10,15 \%$ in natural matter) with six repetitions and the control treatment (exclusive silage elephant grass). Increasing linear effect was observed for each unit added glycerin percentage in natural matter $(\mathrm{MN})$ an increase of $0.36 \%$ in the DM content of silages and increase of $0.32 \%$ in the ether extract. The fermentative quality of silage there was no difference in $\mathrm{pH}$ between the control silage and added with glycerine, with an average of 3.91. The degradability of the fiber, the addition of crude glycerin up to $15 \%$ increased by $7.2 \% ; 53.8 \%$ and $36.5 \%$, respectively, the insoluble fraction, but potentially degradable standardized "bp", degradation rate of the fraction "bp", "c" and effective degradability, respectively. Inclusion of $15 \%$ glycerin in natural matter improves the composition bromatological fermentative profile and ruminal degradation of dry matter and fiber fraction.
\end{abstract}

Key words: Silage. Glycerol. Grass. Pennisetum.

\section{Resumo}

Objetivou-se avaliar o melhor nível de inclusão de glicerina bruta em silagens de capim elefante (Pennisetum purpureum Schum.) sobre o perfil fermentativo, composição bromatológica e degradação ruminal da matéria seca e fração fibrosa. $\mathrm{O}$ experimento foi realizado em um delineamento inteiramente casualizado sendo utilizado o capim-elefante cv. Napier com quatro níveis de inclusão de glicerina (1, $5,10,15 \%$ na matéria natural) com seis repetições e o tratamento controle (silagem exclusiva de capimelefante). Foi observado efeito linear crescente para cada unidade percentual de glicerina adicionada na matéria natural (MN) com incremento de $0,36 \%$ no teor de MS das silagens e aumento de $0,32 \%$ no extrato etéreo. Quanto a qualidade fermentativa da silagem não houve diferença nos valores de $\mathrm{pH}$ entre a silagem controle e as aditivadas com glicerina, apresentando média de 3,91. Quanto à degradabilidade da fibra, a adição de glicerina bruta em até $15 \%$ aumentou $7,2 \% ; 53,8 \%$ e $36,5 \%$, respectivamente, a fração insolúvel, mas potencialmente degradável padronizada "Bp", taxa de degradação da fração "Bp" "c" e degradabilidade efetiva, respectivamente. A inclusão de $15 \%$ da glicerina na matéria natural

\footnotetext{
1 Profs., Universidade Estadual de Montes Claros, UNIMONTES, Janaúba, MG, Brasil. E-mail: joao.rigueira@unimontes.br; eleusa.sales@unimontes.br; jmchamone@gmail.com; vicente.rocha@unimontes.br; piresdaa@gmail.com

2 Pesquisador de Pós-Doutorado, UNIMONTES, Janaúba, MG, Brasil. E-mail: moncaomoncao@yahoo.com.br

3 Prof., Universidade Federal de Sergipe, UFSE, Sertão, SE, Brasil. E-mail: satcreis@gmail.com

4 M.e, em Zootecnia, UNIMONTES, Janaúba, MG, Brasil. E-mail: lara_brantt@hotmail.com

* Author for correspondence
} 
melhora a composição bromatológica, perfil fermentativo e degradação ruminal da matéria seca e fração fibrosa.

Palavras-chave: Ensilagem. Glicerol. Gramíneas. Pennisetum.

\section{Introduction}

The production of silage as roughage for animals is a widely used practice to address dry season food shortages (RIGUEIRA et al., 2017). Of the grasses used to make silage, elephant grass (Pennisetum purpureum Schum.) stands out as a tropical forage due to its high dry matter production by area (50 to $80 \mathrm{tha}^{-1}$ ), ease of cultivation, and acceptance by animals and high nutritional value (DÓREA et al., 2013; LOBO et al., 2014). However, the high moisture content in grasses, which occurs when their nutritional value is optimal, is an obstacle to their use as silage because it results in undesirable fermentation (OLIVEIRA et al., 2014). Forages ensiled with high moisture content (above $75 \%$ ) facilitate the development of deteriorating microorganisms, such as those in the genus Clostridium, that in addition to consuming lactic acid, which is essential for lowering the $\mathrm{pH}$ of silages, degrade protein, causing the amount of ammoniacal nitrogen to decline (DIAS et al., 2014). Furthermore, a low dry matter content may favor the production of large quantities of effluents, which carry highly digestible nutrients, sugars, and organic acids, thus reducing the nutritive value of the silage (RIGUEIRA et al., 2017).

These limitations can be minimized with additives aimed at improving the fermentation profile and minimizing dry matter losses through effluents and gases. Among the potential additives, crude glycerin has a high dry matter content (90\%) and a high glycerol content (80\%), which can be a source of energy for fermentative bacteria, and it is also highly available due to the recent increase in biodiesel production that has caused the prices of this industrial by-product to decrease, making its use attractive (DIAS et al., 2014; GOMES et al., 2015; RIGUEIRA et al., 2017).
Approximately $7.9 \mathrm{~kg}$ of crude glycerin is produced for every 100 liters of biodiesel (THOMPSON; HE, 2006). Thus, the existing biodiesel industry can produce sufficient crude glycerin for use in the production of chemicals and fuel additives as well as a source of energy in the diets of animals (GUNN et al., 2010; LEONETI et al., 2012).

However, there have been few studies of how the addition and level of inclusion of crude glycerin during the ensiling process affects digestibility. It is interesting to study crude glycerin as an additive because of its high availability due to biodiesel production and the possibility of decreasing energetic losses from elephant grass silage.

In this context, the objective of this study was to evaluate the best level of inclusion of crude glycerin in elephant grass silage in terms of its effects on the fermentation profile, bromatological composition, and ruminal degradation of the dry matter and the fibrous fractions.

\section{Materials and Methods}

The experiment was conducted in the Agrarian Sciences sector of the State University of Montes Claros, Janaúba Campus. The average annual rainfall at the site is $800 \mathrm{~mm}$ with an average annual temperature of $28{ }^{\circ} \mathrm{C}$ and a relative humidity of approximately $65 \%$, and according to the Köppen classification, the predominant climate in the region is Aw (ANTUNES, 1994).

Elephant grass cv. Napier (Pennisetum purpureum Schum.) was used with four levels of glycerin inclusion $(1 \%, 5 \%, 10 \%$ and $15 \%$ of the natural matter) in a completely randomized design with six replicates and a control treatment (elephant grass silage without an additive). The chemical 
composition of the glycerin and the Napier Bromatology and Animal Nutrition of Unimontes, elephant grass was analyzed at the Laboratory of and the results are presented in Table 1.

Table 1. Guaranteed glycerin levels and the chemical composition of the elephant grass in natura, $\%$ dry matter.

\begin{tabular}{lcc}
\hline Item & Crude glycerin (\%) & Elephant grass (\%) \\
\hline Total glycerol & 86.9 & - \\
Dry matter & 89.5 & 20.8 \\
Methanol & $<0.01$ & - \\
$\mathrm{pH}$ & 5.3 & - \\
Humidity & 9.2 & - \\
Crude protein & 0.4 & 5.4 \\
Neutral detergent fiber & - & 75.0 \\
Acid detergent fiber & - & 44.0 \\
Fat & 0.1 & 2.7 \\
Ash & 3.2 & 5.9 \\
Sodium & 1.3 & - \\
Chlorine & 1.9 & - \\
Potassium & $<0.1$ & - \\
\hline
\end{tabular}

The forage was collected from pre-selected areas at the UNIMONTES Experimental Farm when it reached 2 meters in height. The grass was cut manually and later crushed in a crusher-chopper machine coupled to an electric motor; the knives in the machine were set to grind the forage to a particle size of $2 \mathrm{~cm}$. The forage was harvested from five hills, and the additive was added in the respective proportions and homogenized before ensiling.

To produce the silage, experimental PVC silos of known weight were used that were $40 \mathrm{~cm}$ long and $10 \mathrm{~cm}$ in diameter. The bottom of the silos contained $10 \mathrm{~cm}$ of dry sand that was separated from the forage by foam to quantify the amount of effluent produced, and after the complete homogenization of the forage with the additives, the resultant material was deposited in the silos and compacted with a wooden plunger. For each treatment, the silage density $\left(550 \mathrm{~kg}\right.$ of natural material $\mathrm{m}^{-3}$ ) was quantified, and approximately $3 \mathrm{~kg}$ of the chopped material of each fresh forage was quantified, as recommended by Ruppel et al. (1995). After filling, the silos were closed with PVC caps fitted with Bunsen valves, sealed with adhesive tape and weighed.

The silos were stored at room temperature on the premises of the Laboratory of Food Analysis of UNIMONTES, and they were opened 60 days after ensiling. Samples were then collected from the middle of each silo after discarding the silage at the top, where fungi were present, and then pre-dried by forced ventilation at $55^{\circ} \mathrm{C}$ to a constant weight. Subsequently, some of the pre-dried material was milled in Willey mill with 1-mm sieves (to analyze chemical composition), and the remainder of the samples were milled with $5-\mathrm{mm}$ sieves (in situ degradability assay) and stored in properly identified plastic pots. The silage fermentation analyses were performed as follows: $\mathrm{pH}$ was determined using a potentiometer (digital) according to the methodology described by Silva and Queiroz (2006), and ammoniacal nitrogen, expressed as total nitrogen ( $\left.\mathrm{N}-\mathrm{NH}_{3}, \% \mathrm{DM}\right)$, was analyzed using an approximately 25 -g silage sample, as proposed by Bolsen et al. (1992). 
The dry matter losses from the silages in the forms of gases and effluent were quantified by differences in weight, according to (JOBIM et al., 2007). The effluent losses were obtained using the following equation:

$\mathrm{E}=(\mathrm{Pab}-\mathrm{Pen}) /(\mathrm{Mvfe}) \times 1000$, where:

$\mathrm{E}$ : effluent production ( $\mathrm{kg} /$ ton of green mass);

Pab: set weight (bucket + cover + wet sand + foam) at silo opening ( $\mathrm{kg})$;

Pen: set weight (bucket + cover + wet sand + foam) at silo opening $(\mathrm{kg})$;

Mvfe: green forage mass ensiled (kg).

The loss of dry matter in the form of gases was calculated from the difference between the gross weight of the initial and final ensiled dry matter relative to the amount of silage MS after discounting the weight of the silo and dry sand, according to the following equation:

$$
\mathrm{G}=\left[(\text { Pcen }- \text { Pen })^{*} \text { Msen }\right]-\left[(\text { Pcab-Pen })^{*} \text { Msab }\right]
$$
x 100 [(Pcen - Pen $)^{*}$ Msen], where:

$\mathrm{G}$ : gas losses (\% DM);

Pcen: weight of the bucket when full of silage $(\mathrm{kg})$;

Pen: set weight (bucket + cover + wet sand + cloth) at silo opening (kg);

Msen: dry matter content of ensiled forage;

Pcab: weight of the fill bucket full at silo opening (kg);

Msab: dry matter content of the forage at silo opening.

The pre-dried forage was then analyzed for the contents of dry matter (DM, 934.01), mineral matter (ash, 942.05), ether extract (EE; 920.39), and crude protein $(\mathrm{CP}, 978.04)$ as described by the AOAC (1995). Neutral detergent fiber (NDF) and acid detergent fiber (ADF) were determined by the sequential method according to procedures described by Robertson and Van Soest (1981) using a TECNAL® ${ }^{\circledR}$ TE-149 fiber determiner (Piracicaba, SP, Brazil). Cellulose was solubilized in $72 \%$ sulfuric acid, and the lignin content was obtained from the resulting difference in weight (GOERING; VAN SOEST, 1970). The contents of neutral detergent insoluble nitrogen (NDIN) and acid detergent insoluble nitrogen (ADIN) were determined according to Licitra et al. (1996), and the levels of neutral detergent insoluble protein (NDIP) and acid detergent insoluble protein (ADIP) were obtained by multiplying the NDIN and ADIN by 6.25 , respectively.

To evaluate the ruminal degradation kinetics, two crossbred cannulated steers with a mean weight of $450 \mathrm{~kg}$ were used. The animals received $3.0 \mathrm{~kg}$ of concentrate in two equal portions in the morning and afternoon as well as diets based on elephant grass. The in situ degradability technique was performed using 7.5 x 15-cm non-woven fabric bags (TNT, weight 100) with an approximate porosity of 50 $\mu \mathrm{m}$, according to Casali et al. (2009); the number of samples was determined from the ratio of $20 \mathrm{mg}$ of MS.cm-2 of bag surface area (NOCEK, 1988).

The bags were placed in $20 \times 30-\mathrm{cm}$ fillet bags along with 100-g lead weights. The fillet bags were tied with a nylon thread, leaving a length of $1 \mathrm{~m}$ so that the bags could move freely in the solid and liquid phases of the rumen. The fillet bags were then deposited in the ventral sac region of the rumen with the end of the nylon thread remaining attached to the cannula for $0,6,12,24,48,72$ and 96 hours in reverse order, i.e., starting with the duration of 96 hours. The 0-hour time samples were inserted into the rumen for five minutes. Afterwards, all samples were collected and washed in ice water to stop the ruminal fermentation. Subsequently, the samples were placed in greenhouses at $55^{\circ} \mathrm{C}$ for 72 hours and then cooled in a desiccator and weighed.

The residues remaining in the TNT following collection from the rumen were analyzed for DM and NDF contents. The percent degradation was calculated by the proportion of food remaining in 
the bags after ruminal incubation, and the NDF was analyzed according to the methods proposed by Van Soest et al. (1991) without the use of $\alpha$-amylase. The obtained data were adjusted to a non-linear regression by the Gauss-Newton method (NETER et al., 1985) using SAS software (SAS, 2008), according to the equation proposed by Ørskov and Mcdonald (1979): $\mathrm{Y}=\mathrm{a}+\mathrm{b}\left(1-\mathrm{e}^{-\mathrm{ct}}\right)$, where $\mathrm{Y}$ $=$ the cumulative degradation of the nutritional component analyzed after time $\mathrm{t} ; \mathrm{a}=$ the degradation curve intercept when $\mathrm{t}=0$, which corresponds to the water-soluble fraction of the analyzed nutrient component; $\mathrm{b}=$ the degradation potential of the water-insoluble fraction of the analyzed nutrient component; $\mathrm{a}+\mathrm{b}=$ the degradation of the analyzed nutritional component when time is not a limiting factor; $\mathrm{c}=$ the rate of degradation per fermentative action of $b$; and $t=$ incubation time.

Once calculated, the coefficients $\mathrm{a}, \mathrm{b}$ and $\mathrm{c}$ were applied to the equation proposed by Ørskov and McDonald (1979): $\mathrm{ED}=\mathrm{a}+(\mathrm{bc} / \mathrm{c}+\mathrm{k})$, where $\mathrm{ED}=$ the effective degradability of the nutritional component, and $\mathrm{k}=$ the feed passage rate. The particle passage rate through the rumen was estimated to be $5 \% \mathrm{~h}^{-1}$, as suggested by AFRC (1993).

The NDF degradability was estimated using the model of Mertens and Loften (1980): Rt = B $\mathrm{x}^{-\mathrm{ct}}+\mathrm{I}$, where $\mathrm{Rt}=$ the fraction degraded in time $\mathrm{t} ; \mathrm{B}=$ the potentially degradable insoluble fraction; and $\mathrm{I}=$ the indigestible fraction. After adjusting the NDF degradation equation, the fractions were standardized as proposed by Waldo et al. (1972) using the equations: $\mathrm{BP}=\mathrm{B} /(\mathrm{B}+\mathrm{I}) \times 100$ and $\mathrm{IP}=\mathrm{I} /(\mathrm{B}+\mathrm{I}) \times 100$, where $\mathrm{BP}=$ the standardized potentially degradable fraction $(\%) ; \mathrm{IP}=$ the standardized indigestible fraction $(\%) ; \mathrm{B}=$ the potentially degradable insoluble fraction; and $\mathrm{I}=$ the indigestible fraction. The effective degradability of the NDF was calculated using the model DE $=\mathrm{BP} x$ $\mathrm{c} /(\mathrm{c}+\mathrm{k})$, where BP is the standardized potentially degradable fraction $(\%)$.

The collected data were submitted to analysis of variance, and when the result of the "F" test was significant, each level of glycerin inclusion was compared to the control by Dunnett's test using the SAS PROC GLM function (SAS, 2008). Furthermore, the glycerin inclusion levels were subjected to regression analysis, excluding the control, and the fit of the effects of crude glycerin inclusion to linear, quadratic and cubic models was evaluated. For all statistical procedures, $\alpha=0.05$ was used as the tolerable maximum limit for type III error. If two models (e.g., linear and quadratic) were significant, we opted for the model with the highest-degree polynomial.

\section{Results and Discussion}

The mean $\mathrm{pH}$, ammoniacal nitrogen, effluent loss and gas loss values are shown in Table 2. There was no difference $(\mathrm{P}=0.22)$ in $\mathrm{pH}$ values between the control silage and the silages with glycerin additive; each presented mean values of 3.91. Tomich et al. (2004) reported that $\mathrm{pH}$ values between 3.8 and 4.2 are adequate for well-preserved silages since this range restricts the proteolytic enzymes of the plant as well as the enterobacteria and clostridia, resulting in appropriate fermentation of all silages.

The $\mathrm{N}-\mathrm{NH}_{3}$ content, expressed as a percentage of the total nitrogen, is widely used in the evaluation of silages because it indicates the degree of proteolysis that occurs during fermentation, and together with the $\mathrm{pH}$ value, it provides an indication of how the fermentation process performed (EVANGELISTA et al., 2004). McDonald and Henderson (1981) inferred that a lack of stability during silage fermentation results in the extensive degradation of amino acids into ammonia, carbon dioxide $\left(\mathrm{CO}_{2}\right)$ and amines, thereby increasing the $\mathrm{N}-\mathrm{NH}_{3}$ content. The inclusion of crude glycerin at $15 \%$ reduced the $\mathrm{N}-\mathrm{NH}_{3}$ content relative to that of the control silage (11.9\%; P <0.01), which implied that the amount of additive efficiently improved the fermentative profile of elephant grass silage, even without altering the $\mathrm{pH}$. Using the same levels of crude 
glycerin as in this research with ensiled Cynodon dactylon cv. Tifton 85, Rigueira et al. (2017) found an $8.3 \%$ reduction in the $\mathrm{N}_{-} \mathrm{NH}_{3}$ content with $15 \%$ inclusion.

Table 2. Mean effluent loss, gas loss, $\mathrm{pH}$ and ammoniacal nitrogen $\left(\mathrm{N}^{-\mathrm{NH}_{3}}\right)$ values of elephant grass silages supplemented with different levels of glycerin.

\begin{tabular}{|c|c|c|c|c|c|c|c|}
\hline \multirow{2}{*}{ Parameter } & \multicolumn{5}{|c|}{ Inclusion of glycerin (\% NM) } & \multirow{2}{*}{ CV (\%) } & \multirow{2}{*}{$P$} \\
\hline & Control & 1 & 5 & 10 & 15 & & \\
\hline $\mathrm{pH}$ & 4.1 & 4.3 & 4.0 & 3.9 & 3.2 & 3.87 & 0.22 \\
\hline $\mathrm{N}-\mathrm{NH}_{3}{ }^{1}(\% \mathrm{NT})$ & 11.9 & 9.1 & $5.0^{*}$ & $7.5^{*}$ & $7.3^{*}$ & 19.95 & $<0.01$ \\
\hline $\operatorname{Gases}^{2}(\% \mathrm{MS})$ & 6.6 & 7.1 & 5.2 & 4.8 & $3.9^{*}$ & 14.67 & 0.02 \\
\hline Effluent $^{3}\left(\mathrm{~kg} . \mathrm{tMV}^{-1}\right)$ & 51.3 & 49.7 & 40.7 & 37.2 & $28.5^{*}$ & 18.19 & 0.04 \\
\hline
\end{tabular}

*Significant by Dunnett's test $(\mathrm{P}<0.05) ; \mathrm{pH}$ - hydrogen potential; $\mathrm{N}-\mathrm{NH}_{3}-$ ammonia nitrogen $(\%$ total nitrogen; $\mathrm{TN})$; NM - natural matter; $\mathrm{CV}$ - coefficient of variation $(\%) ; P$ - probability; ${ }^{1} \mathrm{Y}=9.19-0.72 \mathrm{X}+0.04 \mathrm{X}^{2}\left(\mathrm{R}^{2}=0.41\right) ;{ }^{2} \mathrm{Y}=6.86-0.21 \mathrm{X}\left(\mathrm{R}^{2}=0.88\right) ;{ }^{3}$ $\mathrm{Y}=50.02-1.14 \mathrm{X}\left(\mathrm{R}^{2}=0.96\right)$.

According to McDonald et al. (1991), who classified silage quality based on the ammoniacal nitrogen content relative to the total nitrogen content, a less than $10 \%$ reduction in the $\mathrm{N}^{-\mathrm{NH}_{3}}$ content is considered very good; between 10 to $15 \%$ is adequate; between 15 and $20 \%$ is acceptable; and values above $20 \%$ are unsatisfactory. Based on this classification, the addition of glycerin effectively reduced losses during the fermentation process of elephant grass silage production.

The levels of inclusion of crude glycerin as an additive to elephant grass at the time of silage had a negative linear effect $(\mathrm{P}<0.05)$ on the production of effluents, gases and $\mathrm{N}-\mathrm{NH}_{3}$. By adding crude glycerin to elephant grass silage at the levels of 5,10 , and $15 \%$, the $\mathrm{N}-\mathrm{NH}_{3}$ losses by gases and effluents were reduced by $63 \%, 69.2 \%$ and $80 \%$, respectively.

Effluent production is influenced by the dry matter content of the ensiled crop, silo type, degree of compaction and the physical processing of the forage. The reduction in $\mathrm{N}-\mathrm{NH}_{3}$ losses in this study was possibly due to the increase in the dry matter content of the silage with the addition of glycerin. On the other hand, gas losses are associated with the fermentation profile of the silage, so lower losses are caused by homofermentative bacteria that use glucose as a substrate for lactate synthesis. Higher gas production is associated with heterofermentative bacteria, enterobacteria and yeasts, especially butyric fermentation caused by bacteria of the genus Clostridium sp.

The inclusion of crude glycerin at the time of ensiling elephant grass affected $(\mathrm{P}<0.05)$ the DM, EE, NFC and TDN contents compared to the chemical composition of the control silage, with increases of $27.4,58.3,58.1$ and $22.5 \%$, respectively. In terms of the ash, CP, NDF, ADF, NDIP, ADIP, TC and hemicellulose contents, glycerin addition had no effect when compared to the control silage, and there no differences between the levels of inclusion with mean values of 5.4, 5.1, 67.6, 46.3, 15.6, 9.8, 86.8 and $18.9 \%$, respectively (Table 3 ). 
Table 3. Chemical composition of elephant grass silage with different levels of crude glycerin inclusion.

\begin{tabular}{|c|c|c|c|c|c|c|c|}
\hline \multirow{2}{*}{ Parameter (\% DM) } & \multicolumn{5}{|c|}{ Glycerin inclusion (\% NM) } & \multirow{2}{*}{ CV $(\%)$} & \multirow{2}{*}{$P$} \\
\hline & Control & 1 & 5 & 10 & 15 & & \\
\hline Dry matter $(\%)^{1}$ & 18.8 & 21.2 & 22.3 & $25.1^{*}$ & $25.9^{*}$ & 6.44 & 0.01 \\
\hline Ash & 5.8 & 5.8 & 5.3 & 5.7 & 4.6 & 17.39 & 0.51 \\
\hline Crude protein & 4.7 & 6.00 & 5.3 & 4.6 & 4.7 & 15.25 & 0.21 \\
\hline Ether extract ${ }^{2}$ & 2.4 & 1.9 & 3.1 & $5.4^{*}$ & $6.1^{*}$ & 15.34 & $<0.01$ \\
\hline Neutral detergent fiber & 71.6 & 67.0 & 67.2 & 64.9 & 67.2 & 4.55 & 0.18 \\
\hline Acid detergent fiber & 50.1 & 46.4 & 44.7 & 46.0 & 44.1 & 6.46 & 0.19 \\
\hline NDIP & 21.0 & 12.0 & 17.0 & 11.0 & 17.0 & 45.54 & 0.42 \\
\hline ADIP & 7.0 & 7.0 & 14.0 & 10.0 & 11.0 & 46.45 & 0.34 \\
\hline Total carbohydrates & 86.4 & 86.9 & 87.1 & 86.6 & 87.3 & 1.63 & 0.89 \\
\hline Hemicelullose & 20.4 & 19.0 & 22.5 & 13.7 & 15.5 & 19.43 & 0.01 \\
\hline Non-fibrous carbohydrates ${ }^{3}$ & 18.3 & 24.8 & 25.5 & $* 41.9$ & $* 45.5$ & 17.87 & $<0.01$ \\
\hline Total digestible nutrients ${ }^{4}$ & 46.6 & 48.9 & $* 52.2$ & $* 62.5$ & $* 65.7$ & 3.21 & $<0.01$ \\
\hline
\end{tabular}

DM - dry matter content; NDIP - neutral detergent insoluble protein; ADIP - acid detergent insoluble protein; NM - natural matter. ${ }^{*}$ Significant by Dunnett's test $(\mathrm{P}<0.05) ;{ }^{1} \hat{\mathrm{Y}}_{\mathrm{DM}}=20.8+0.36 \mathrm{X}\left(\mathrm{R}^{2}=0.95\right) ;{ }^{2} \hat{\mathrm{Y}}_{\mathrm{EE}}=1.7+0.32 \mathrm{X}\left(\mathrm{R}^{2}=0.96\right) ;{ }^{3} \hat{\mathrm{Y}}_{\mathrm{NFC}}=14.8+7.8 \mathrm{X}\left(\mathrm{R}^{2}\right.$ $=0.88) ;{ }^{4} \hat{\mathrm{Y}}_{\mathrm{TDN}}=42.1+6.1 \mathrm{X}\left(\mathrm{R}^{2}=0.95\right) ; \mathrm{CV}$ - coefficient of variation; $\mathrm{P}$ - probability.

Among the inclusion levels, the DM values best fit the linear regression model with a marginal variation of $18.1 \%$. For each level of glycerin addition as a percentage of the natural matter (NM), there was a $0.36 \%$ increase in the DM content of the silages that was due to the high dry matter content of glycerin (89.5\%, Table 1), which is a desirable feature in an additive when ensiling grasses with high moisture contents. According to McDonald et al. (1991), silages made from forages with low dry matter contents can promote the development of bacteria of the genus Clostridium, which produce butyric acid and cause the degradation of protein and lactic acid. Butyric acid formation results in large losses of dry matter due to the production of $\mathrm{CO}_{2}, \mathrm{H}_{2} \mathrm{O}$ and energy. In addition, when ensiled with a high moisture content, a significant proportion of the nutrients is lost from elephant grass due to effluent production (LOURES et al., 2003).

An increasing linear effect with the addition of glycerin was observed on the ether extract content of the silages. The $0.32 \%$ increase for each $1 \%$ of added glycerin was possibly due to the residual lipids in the glycerin. Lipids are the result of incomplete esterification with alcohol to produce biofuel, and the marginal variation among the lowest and highest inclusion levels was $68.8 \%$. The observed EE content ( $6.1 \%$ of DM) with glycerin addition at $15 \%$ does not exceed that recommended by NRC (2007), which stipulates a limit of $8 \%$ of this nutrient in the MS of the diet to prevent interference with the ruminal fermentation rate, the feeding rate and digestibility. This increase in EE content may be beneficial by increasing the energy density of the diet since lipids provide 2.25 times more energy than carbohydrates and protein. Lage et al. (2010), evaluating the performance of sheep with increasing levels of substitution of grain corn for glycerin in the diet, observed an increase of 36.84 percentage units of EE in the dry matter with $12 \%$ substitution.

The crude protein values in the silages, which averaged $5.04 \%(\mathrm{P}>0.05)$, suggest that exclusively supplying elephant grass silage without crude glycerin as a source of nitrogen for ruminants does not meet the minimum requirements for the growth 
and development of ruminal microorganisms, which is 7\% according to VAN SOEST (1994). Thus, it is important to supplement animal diets with ingredients that have a high nitrogen content $(\mathrm{N})$.

The inclusion of crude glycerin increased the NFC content in the silages by $45.5 \%$ (marginal variation), which is supported by the increase in EE content; there was a $7.8 \%$ increase in the NFC content for each percentage unit of added glycerol. The high availability of NFC in the rumen implies an increase in the synthesis of propionic acid; even when $\mathrm{N}$ availability is high, rapid degradation may increase the synthesis of microbial proteins and, consequently, animal performance (MACH et al., 2009). Ruminants can utilize the glycerol in crude glycerin as a gluconeogenic precursor (CHUNG et al., 2007) for the maintenance of plasma glucose levels. In this way, glycerol can also be included in silages as a less expensive and more readily available alternative energy ingredient to other commonly used energy sources. The observed 25\% increase in NDT contents (marginal variation) (P $<0.05$ ) corroborates the improvement of the silage energy content.

The addition of crude glycerin improved the concentration of the readily soluble "a" fraction, the degradation rate of the insoluble " $b$ " and "c" fractions, the potential degradability (PD) and the effective degradability (ED) of the dry matter content of elephant grass silage (Table 4).

Table 4. Ruminal degradation parameters of the dry matter of elephant grass silage with different levels of crude glycerin.

\begin{tabular}{lccccccc}
\hline \multirow{2}{*}{ Parameters } & \multicolumn{9}{c}{ Glycerin inclusion (\% of NM) } & CV (\%) & $P$ \\
\cline { 2 - 5 } & Control & 1 & 5 & 10 & 15 & & \\
\hline Fraction "a"1 & 9.9 & $* 13.4$ & $* 18.7$ & $* 25.0$ & $* 27.6$ & 1.70 & $<0.01$ \\
Insoluble fraction "b" & 25.9 & 25.2 & $* 22.5$ & $* 17.6$ & $* 18.0$ & 2.67 & $<0.01$ \\
Rate of degradation of "c"3 & 0.03 & 0.03 & 0.03 & $* 0.05$ & 0.03 & 5.85 & $<0.01$ \\
Potential degradability & 35.8 & $* 38.7$ & $* 41.3$ & $* 42.7$ & $* 45.6$ & 0.86 & $<0.01$ \\
Undegradable fraction & 64.2 & 61.3 & $* 58.7$ & $* 57.3$ & $* 54.4$ & 2.88 & $<0.01$ \\
Effective degradability & 19.9 & $* 22.7$ & $* 27.7$ & $* 34.3$ & $* 34.1$ & 1.09 & $<0.01$ \\
\hline
\end{tabular}

${ }^{1}$ Fraction readily soluble "a"; ${ }^{2}$ Fraction insoluble but potentially degradable " $b$ "; ${ }^{3}$ Rate of fraction degradation " $b$ " "c". * Significant by Dunnett's test $(\mathrm{P}<0.05) ;{ }^{1} \hat{\mathrm{Y}}=13.16+1.03 \mathrm{X}\left(\mathrm{R}^{2}=0.96\right) ;{ }^{2} \hat{\mathrm{Y}}=25.15-0.56 \mathrm{X}\left(\mathrm{R}^{2}=0.86\right) ;{ }^{4} \hat{\mathrm{Y}}=38.44+0.47 \mathrm{X}\left(\mathrm{R}^{2}=0.98\right) ;{ }^{5} \hat{\mathrm{Y}}=$ 61.55- 0.47X $\left(\mathrm{R}^{2}=0.98\right) ;{ }^{6} \hat{\mathrm{Y}}=23.09+0.85 \mathrm{X}\left(\mathrm{R}^{2}=0.87\right) ; \mathrm{CV}-$ coefficient of variation; $\mathrm{P}-$ probability.

The observed increases in the DM, EE and CNF contents may explain the $64.1 \%$ increase $(\mathrm{P}<0.05)$ in the contents of the "a" fraction with the addition of crude glycerin. Among the inclusion levels, the increase was $1.03 \%$ for each percentage unit of glycerin added. The "a" fraction of the DM includes the carbohydrates in foods that are readily soluble when in contact with water and microorganisms in the rumen, and when solubilized and fermented, it produces short-chain fatty acids, ammonia and microbial protein, which are energy sources for ruminants.
The addition of $1 \%$ crude glycerin at silage did not change the " $\mathrm{b}$ " contents, which averaged $25.5 \%$, relative to the control silage but with the application of up to $15 \%$ glycerin, there was a $30.5 \%$ reduction $(\mathrm{P}<0.05)$. However, the degradation rate of the " $\mathrm{b}$ " and "c" fractions, PD and ED increased by $40 \%$, $21.5 \%$ and $41.4 \%$, respectively $(\mathrm{P}<0.05)$ with the addition of crude glycerin. These increases are related to those observed in the "a" fraction since this fraction is a participatory component in the quantification of PD and ED. PD is related to the fraction of the food with degradation potential in 
the rumen, and ED is associated with the fraction that is affected by the action of the ruminal microorganisms. The undegradable fraction (UF) of the DM was influenced by crude glycerin levels ( $\mathrm{P}<0.05$ ), with a $0.47 \%$ reduction for each $1 \%$ of glycerin added in the $\mathrm{MN}$ of elephant grass during ensiling.

Jenkins and Palmquist (1984), Firkins et al. (2007) and Abubakr et al. (2013) noted that in some studies, the addition of saturated lipids in the diet reduces the degradability of the fibrous fraction of the food depending on the level of inclusion. However, the addition of crude glycerin at up to $15 \%$ in this study increased the Bp by $7.2 \%$, and the degradation rate of the "Bp" and " $\mathrm{c}$ " fractions and the ED $(\mathrm{P}<0.05)$ of the neutral detergent fiber were found to be insoluble but potentially degradable at $53.8 \%$ and $36.5 \%$, respectively, compared to the control silage (Table 5).

Table 5. Ruminal degradation parameters of neutral detergent fiber of elephant grass silage associated with different levels of crude glycerin.

\begin{tabular}{lccccccc}
\hline \multirow{2}{*}{ Parameters } & \multicolumn{9}{c}{ Inclusion of Glycerin $(\%$ of NM) } & \multirow{2}{*}{ CV (\%) } & $P$ \\
\cline { 2 - 5 } & Control & 1 & 5 & 10 & 15 & & \\
\hline $\mathrm{Bp}^{1}$ & 68.6 & 71.0 & 71.0 & 66.6 & $* 73.9$ & 2.43 & $<0.01$ \\
$\mathrm{c}^{2}$ & 0.05 & $* 0.06$ & $* 0.07$ & $* 0.08$ & $* 0.13$ & 9.35 & $<0.01$ \\
$\mathrm{ED}^{3}$ & 34.5 & $* 39.0$ & $* 42.7$ & $* 40.8$ & $* 54.3$ & 1.52 & $<0.01$ \\
$\mathrm{Ip}^{4}$ & 31.4 & 29.0 & 29.0 & 33.4 & $* 26.0$ & 5.72 & $<0.01$ \\
\hline
\end{tabular}

${ }^{1}$ Standardized insoluble but potentially degradable fraction $(\mathrm{Bp}) ;{ }^{2}$ rate of degradation of Bp fraction ${ }^{\odot} ;{ }^{3}$ effective degradability (ED); ${ }^{4}$ standardized undegradable fraction (Ip). ${ }^{*}$ Significant by Dunnett's test $(\mathrm{P}<0.05) ;{ }^{1} \hat{\mathrm{Y}}=73.19-1.37 \mathrm{X}+0.09 \mathrm{X}^{2}\left(\mathrm{R}^{2}=0.60\right)$; ${ }^{2} \hat{\mathrm{Y}}=0.048+0.0047 \mathrm{X}\left(\mathrm{R}^{2}=0.86\right) ;{ }^{3} \hat{\mathrm{Y}}=36.91+0.94 \mathrm{X}\left(\mathrm{R}^{2}=0.69\right) ;{ }^{4} \hat{\mathrm{Y}}=26.80+1.3752 \mathrm{X}-0.0921 \mathrm{X}^{2}\left(\mathrm{R}^{2}=0.60\right)$.

In dairy cows, Wilbert et al. (2013) found that the addition of crude glycerin at 4,8 and $12 \%$ for each kilogram of DM increased the glucose circulating in the blood stream and did not affect the consumption of DM and the fibrous fraction of sorghum silage-based diets. Therefore, ruminal degradation of the fibrous fraction was not affected at the levels used, a similar behavior to that observed for fiber degradation in this study. It should be highlighted that the increased NFC and TDN in the rumen increased the energy available for bacteria to degrade the fibrous fraction of the elephant grass silage, which can be verified by the $0.0047 \%$ increase in the degradation rate of the "Bp" fraction and the $0.94 \%$ increase in ED for each percentage unit of crude glycerin added at the time of ensiling.

In lamb diets containing 30\% corn silage, Lage et al. (2010) verified that the inclusion of crude glycerin at $7.26 \%$ maximizes the degradability of the fibrous fraction. Furthermore, the authors observed that inclusion above $6 \%$ reduces DM consumption and, consequently, performance. Botini et al. (2015) also found a reduction in DM intake with the substitution of corn for glycerin, which may be due to mechanisms that inhibit the growth and activity of cellulolytic and protozoan bacteria (TAMMINGA; DOREAU, 1991) as well as the physical coating of fiber by lipids, which hinders the action of microorganisms (JENKINS; McGUIRE, 2006). In this research, even the addition of crude glycerin at the level of $15 \%$ of the NM of elephant grass at the time of ensiling did not negatively affect fiber degradation, and it had positive effects on the chemical composition, fermentative profile and ruminal degradation. 


\section{Conclusion}

The addition of glycerin to elephant grass silage at the level of $15 \%$ of the natural matter improves the fermentation profile, bromatological composition, and ruminal degradation of the dry matter and fibrous fractions. However, further research is needed to clarify the interactions between glycerin and silage and their effects on animal performance.

\section{Acknowledgements}

The authors thank the Foundation for Research Support of the State of Minas Gerais (FAPEMIG), the Banco do Nordeste do Brasil (BNB), the National Council for Scientific and Technological Development (CNPq) and the Coordination for the Improvement of Higher Education Personnel (CAPES) for financial assistance and scholarships (PNPD).

\section{References}

ABUBAKR, A. R.; ALIMON, A. R.; YAAKUB, H.; ABDULLAH, N.; IVAN, M. Digestibility, rumen protozoa, and ruminal fermentation in goats receiving dietary palm oil by-products. Journal of the Saudi Society of Agricultural Sciences, Riyadh, v. 12, n. 2, p. 147-154, 2013.

AGRICULTURALAND FOOD RESEARCH COUNCIL - AFRC. Energy and protein requirements of ruminants. Walligford: CAB International, 1993.

ANTUNES, F. Z. Caracterização climática. Informe Agropecuário, Belo Horizonte, v. 17, n. 181, p. 15-19, 1994.

ASSOCIATION OF OFFICIAL ANALYTICAL CHEMISTS - AOAC. Official methods of analysis of AOAC international. $16^{\text {th }}$ ed. Arlington: Association of Official Analytical Chemists, 1995.

BOLSEN, K. K.; LIN, C.; BRENT, B. E.; GADEKEN, D. Effect of silage additives on the microbial succession and fermentation process of alfalfa and corn silages. Journal of Dairy Science, Madison, v. 75, n. 11, p. 30663083, 1992.

BOTINI, L. A.; MORAES, K. A. K.; MORAES, E. H. B. K.; PINA, D. S.; PAULA, D. C.; HOFFMANN, A.; STINGUEL, H.; SOCREPPA, L. M.; MENESES, D. M.
Glicerina bruta em suplementos para bovinos de corte a pasto no período seco. Pesquisa Agropecuária Brasileira, Brasília, v. 50, n. 3, p. 242-249, 2015.

CASALI, A. O.; DETMANN, E.; VALADARES FILHO, S. C.; PEREIRA, J. C.; CUNHA, M.; DETMANN, K. S. C.; PAUlinO, M. F. Estimação de teores de componentes fibrosos em alimentos para ruminantes em saco de diferentes tecidos. Revista Brasileira de Zootecnia, Viçosa, MG, v. 38, n. 1, p. 130-138, 2009.

CHUNG, Y. H.; RICO, E. D.; MARTINES, M. C.; CASSIDY, T. W.; NOIROT, V.; AMES, A.; VARGA, G. A. Effects of feeding dry glycerin to early postpartum Holstein dairy cows on lactational performance and metabolic profiles. Journal of Dairy Science, Madison, v. 90, n. 12, p. 56825691, 2007.

DIAS, A. M.; ÍTAVO, L. C. V.; ÍTAVO, C. C. B. F.; BLAN, L. R.; GOMES, E. N. O.; SOARES, C. M.; LEAL, E. S.; NOGUEIRA, E.; COELHO, E. M. Ureia e glicerina bruta como aditivos na ensilagem de canade-açúcar. Arquivo Brasileiro de Medicina Veterinária e Zootecnia, Belo Horizonte, v. 66, n. 6, p. 1874-1882, 2014.

DÓREA, J. R. R.; OLIVEIRA, J. S.; SANTOS, E. M.; ZANINE, A. M.; SILVA, T. C.; DANÉS, M. A. C.; FRANCO, A. L. C.; GOUVÊA, V. N.; MIZUBUTI, I. Y. Cinética de degradação ruminal de silagem de capim-elefante com diferentes níveis de jaca e raspa de mandioca. Semina: Ciências Agrárias, Londrina, v. 34, n. 5, p. 2437-2446, 2013.

EVANGELISTA, A. R.; ABREU, J. G.; AMARAL, P. N. C.; PEREIRA, R. C.; SALVADOR, F. M.; SANTANA, R. A. V. Produção de silagem de capim-marandu (Brachiaria brizantha stapf cv. Marandu) com e sem emurchecimento. Ciencia e Agrotecnologia, Lavras, v. 28, n. 2, p. 443-449, 2004.

FIRKINS, J. L.; YU, Z.; MORRISON, M. Ruminal nitrogen metabolism: perspectives for integration of microbiology and nutrition for dairy. Journal of Dairy Science, Madison, v. 90, n. 1, p. 1-16, 2007.

GOERING, H. K.; VAN SOEST, P. J. Forage fiber analysis: apparatus, reagents, procedures and some applications. Washington: USDA, 1970. 20 p.

GOMES, M. A. B.; MORAES, G. V.; JOBIM, C. C.; SANTOS, T. C.; OLIVEIRA, M. R.; ROSSI, R. M. Aerobic stability, chemical composition and ruminal degradability of sugarcane silage with glycerin from biodiesel. Semina: Ciências Agrárias, Londrina, v. 36, n. 3, p. 1531-1544, 2015.

GUNN, P. J.; NEARY, M. K.; LEMENAGER, R. P.; LAKE, S. L. Effects of crude glycerin on performance 
and carcass characteristics of finishing wether lambs. Journal of Animal Science, Champaign, v. 88, n. 1, p. 1771-1776, 2010.

JENKINS, T.C.; MCGUIRE, M.A. Major advances in nutrition: impact on milk composition. Journal of Dairy Science, Madison, v. 89, n. 4, p. 1302-1310, 2006.

JENKINS, T. C.; PALMQUIST, D. L. Effect of fatty acids or calciumsoaps on rumen and total nutrient digestibility of dairy rations. Journal of Dairy Science, Madison, v. 67, n. 5, p. 978-986, 1984.

JOBIM, C. C.; NUSSIO, L. G.; REIS, R. A.; SCHMIDT, P. Avanços metodológicos na avaliação da qualidade da forragem conservada. Revista Brasileira de Zootecnia, Viçosa, MG, v. 36, n. 1, p. 101-119, 2007.

LAGE, J. F.; PAUlinO, P. V.; PEREIRA, L. G. R.; VALADARES, F S. C.; OLIVEIRA, A. S. de; DETMANN, E.; SOUZA, N. K. P.; LIMA, J. C. M. Glicerina bruta na dieta de cordeiros terminados em confinamento. Pesquisa Agropecuária Brasileira, Brasília, v. 45, n. 9, p. 1012-1020, 2010.

LEONETI, A. B.; ARAGAO- LEONETI, V.; OLIVEIRA, S. V. W. B. de. Glycerol as a by-product of biodiesel production in Brazil: alternatives for the use of un refined glycerol. Renewable Energy, Sydney, v. 45, n. 2, p. 138$145,2012$.

LICITRA, G.; HERNANDEZ, T. M.; VAN SOEST, P. J. Standardization of procedures for nitrogen fractionation of ruminant feeds. Animal Feed Science and Technology, Amsterdam, v. 57, n. 4, p. 347-358, 1996.

LOBO, B. S.; SALES, E. C. J.; REIS, S. T.; MONÇÃO, F. P.; PEREIRA, D. A.; RIGUEIRA, J. P. S.; OLIVEIRA, P. M.; MOTA, V. A. C.; ALVES, D. D. Parâmetros morfogênicos e produtividade do capim-Pioneiro submetido a doses de nitrogênio. Semina: Ciências Agrárias, Londrina, v. 35, n. 6, p. 3305-3318, 2014.

LOURES, D. R. S.; GARCIA, R.; PEREIRA, O. G.; CECON, P. R.; SOUZA, A. L. Características do efluente e composição químico-bromatológica da silagem decapim-elefante sob diferentes níveis de compactação. Revista Brasileira de Zootecnia, Viçosa, v. 32, n. 6, p. 1851-1858, 2003.

MACH, N.; BACH, A.; DEVANT, M. Effects of crude glycerin supplementation on performance and meat quality of Holstein bulls fed high-concentrate diets. Journal of Animal Science, Champaign, v. 87, n. 2, p. 632-638, 2009.

MCDONALD, P.; HENDERSON, A. R.; HERON, S. J. E. The biochemistry of silage. $2^{\text {th }}$ ed. Marlow: Chalcomb Publisher, 1991. 340 p.
MERTENS, D. R. E.; LOFTEN, J. R. The effects of starch on forage fiber digestion kinetics in vitro. Journal of Dairy Science, Madison, v. 63, n. 1, p. 1437-1446, 1980.

NATIONAL RESEARCH COUNCIL - NRC. Nutrient requirements of small ruminants. Washington: National Academy, 2007. 362 p.

NETER, J.; WASSERMAN, W.; KUTNER, M.H. Applied linear statistical models. Regression, analysis of variance, and experimental designs. 2. ed. USA, Richard D. Irwin, Inc., 1985. 1127 p.

NOCEK, J. E. In situ and other methods to estimate ruminal protein and energy digestibility: a review. Journal of Dairy Science, Madison, v. 71, n. 8, p. 20512069, 1988.

OLIVEIRA, E. R.; MONÇÃO, F. P.; MOURA, L. V.; GABRIEL, A. M. A.; GÓES, R. H. T. B.; LEMPP, B.; NASCIMENTO, F. A. Valor nutricional de silagem de capim-mombaça com aditivos agroindustriais. Semina: Ciências Agrárias, Londrina, v. 35, n. 3, p. 1543-1556, 2014.

ØRSKOV, E. R.; MCDONALD, I. The estimation of degradability in the rumen form incubation measurement weighted according to rate of passage. Journal of Agricultural Science, Cambridge, v. 92, n. 1, p. 499-508, 1979.

RIGUEIRA, J. P. S.; MONÇÃO, F. P.; SALES, E. C. J.; BRANT, L. M. S.; PIRES, D. A. A.; MATOS, A. M.; LEITE, G. D. O.; SILVA, J. T.; FONSECA, J. D. R.; MOURA, M. M. A.; ROCHA JÚNIOR, V. R. Níveis de glicerina bruta na ensilagem de capim Tifton 85 (Cynodon dactylon): perfil fermentativo e valor nutricional. Revista de Ciências Agrárias, Lisboa, v. 40, n. 3, p. 654-663, 2017.

ROBERTSON, J. B.; VAN SOEST, P. J. The detergent system of analysis and its application to human foods. In: JAMES, W.P. T.; THEANDER, O. The analysis of dietary fiber in food. New York: Marcel Dekker, 1981. p.1 23-158.

RUPPEL, K. A.; PITT, R. E.; CHASE, L. E.; GALTON, D. M. Bunker silo management and its relationship to forage preservation on dairy farms. Journal of Dairy Science, Madison, v. 78, n. 1, p. 141-153, 1995.

SILVA, D. J.; QUEIROZ, A. C. Análise de alimentos: métodos químicos e biológicos. 3. ed. Viçosa, MG: Editora UFV. 2006. 235 p.

STATISTICAL ANALYSIS SYSTEM INSTITUTE SAS Institute. SAS/STAT 9. 2 User's guide. Cary: SAS Institute Inc., 2008. 
TAMMINGA, S.; DOREAU, M. Lipids and rumen digestion. In: JOUANY, J. P. (Ed.). Rumen microbial metabolism and ruminantdigestion. Paris: Institut National de la Recherche Agronomique, 1991. p. 151164.

THOMPSON, J. C.; HE, B. B. Characterization of crude glycerol from biodiesel production from multiple feed stock. Applied Engineering in Agriculture, Miami, v. 22, n. 1, p. 261-265, 2006.

TOMICH, T. R.; GONÇALVES, L. C.; TOMICH, R. G. P.; RODRIGUES, J. A. S.; BORGES, I.; RODRIGUEZ, N. M. Características químicas e digestibilidade in vitro de silagens de girassol. Revista Brasileira de Zootecnia, Viçosa, v. 33, n. 6, p. 1672-1682, 2004.
VAN SOEST, P. J. Nutrition Ecology of the ruminant. 2. ed. Ithaca, NY: Cornell Univ. Press. 1994. 476 p.

VAN SOEST, P. J.; ROBERTSON, J. B.; LEWIS, B. A. Symposium: carbohydrate methodology, and nutritional implications in dairy cattle. Journal Dairy Science, Madison, v. 74, n. 10, p. 3583-3597, 1991.

WALDO, D. R.; SMITH, L. W.; COX, E. L. Model of cellulose disappearance from the rumen. Journal of Dairy Science, Madison, v. 55, n. 1, p. 125-129, 1972.

WILBERT, C. A.; PRATES, E. R.; BARCELLOS, J. O. J.; SCHAFHÄUSER, J. Crude glycerin as an alternative energy feedstuff for dairy cows. Animal Feed Science and Technology, Amsterdam, v. 183, n. 5, p. 116-123, 2013. 